\title{
The Lord's Prayer as a paradigm for restorative justice in brokenness
}

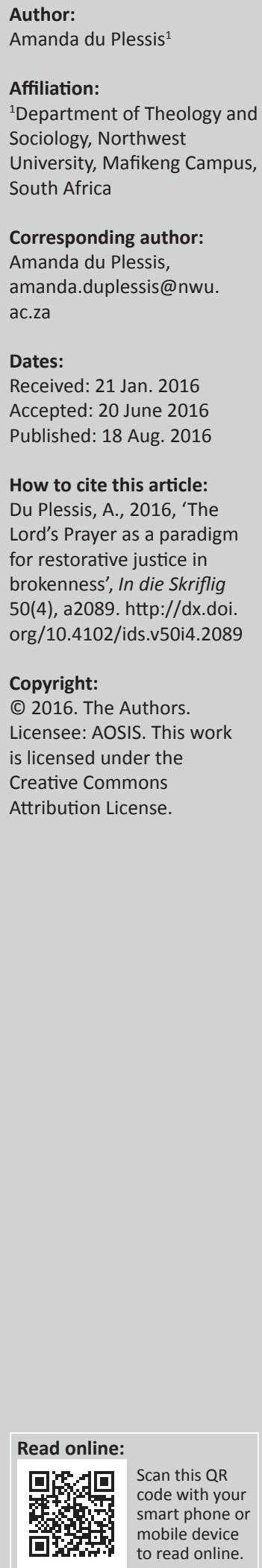

The Lord's Prayer has a collective and an individual sense. In a pastoral context it can lead the individual believer to inner healing, transformation, faith and redemption; with the result of a collective sense of merciful, sacrificing, restorative justice that forms a paradigm for restorative justice in a broken society. Ultimately the Lord's Prayer ripples outwards from the supplicant's own needs to the fulfilment of the love commandment towards God and other people. With the use of the Lord's Prayer in the pastoral guidance process, the counselee's attention can shift from a problem-focused attitude to a life of justice, peace and joy. The research question under investigation asks if the Lord's Prayer can really form a paradigm for restorative justice within a situation of brokenness when it forms part of the pastoral guidance process to give structure to the mixture of emotions that the counselee experiences. The pastoral challenge lies in not limiting newly-found healing to the counselling room, but letting it result in a responsible way of life. Two main themes of the Lord's Prayer are discussed, namely, human beings' relationship with God, and their dependence on God for life. The main themes are related to the love commandment, which in itself aims to guide the believer to the realisation of a wider responsibility towards society in respect of merciful, sacrificing, restorative justice that heals brokenness.

\section{Introductory remarks}

In ecclesiastical communities one comes across the view that the religious beliefs and lifestyle of believers are reflected in the content of their prayers, and vice versa. Koopman (2007:4) described the Lord's Prayer as the heart of the Christian life, as if it is an agenda for the Christian way of life. The Lord's Prayer is assumed to reveal the deepest motives, highest goals and most important priorities of the Christian faith, and how these should be applied as an expression of the Christian theology in everyday life. Throughout Church history, people have marvelled at the Lord's Prayer. Men such as St. Augustine and Martin Luther have observed that there is nothing more wonderful in the entire Bible than the Lord's Prayer; John Calvin stated that the petitions include everything that believers rightly wish from God (Kendall 2010:40; McNair 2005:41). The Lord's Prayer is found in three ancient sources: Matthew 6:9-13, Luke 11:2-4, and Didache ${ }^{1}$ 8:2-3 (McNicol 2004:8). Luke places it within the context of a request from a disciple (Lk 11:1), whilst both Matthew and Didache represent Jesus' teaching on prayer as a contrast to what the hypocrites did (Mt 6:5; Dt 8:1). According to Kendall (2010) the purpose of prayer is to be 'heard' and 'rewarded' and he concluded that:

I have always been comforted by this thought, that whatever I may forget in my own prayers, as long as I pray the Lord's Prayer I have at any rate covered all the principles, the condition, of course, that I am not merely mechanically repeating the words, but am really praying from my heart and with my mind and with my whole being. (pp. 34-35)

Thus said regarding the acknowledged importance of the Lord's Prayer, this article aims to provide normative perspectives regarding the Lord's Prayer in the pastoral guidance process to enable the counselee to lead a life of justice and peace through the working of the Holy Spirit in the life of believers. More specifically, the article investigates the link between the realisation of the responsibilities as found in the Lord's Prayer and restorative justice that can heal brokenness in a community.

\section{Epistemology and research method}

The article proceeds from the epistemology of practical theology and more specifically its pastoral component. According to Müller (2005:73) and Osmer (2008:4), the following definition

1.The Didache dates from about AD 100 and seems to be the product of a late 1st-century Christian-Jewish community in greater Syria. The wording of the Didache's version is very close to that of Matthew. The most striking feature of this version is that it provides the earliest textual evidence for part of the doxological ending to the prayer, 'For your is the power and glory for ever' (McNicol 2004:8). 
describes practical theology best: 'The task of practical theology is to reflect critically on current practices in light of the Scriptures in order to promote growth in the praxis of the faith community'. Although Muller and Osmer each have their own model to reflect on the praxis of the faith community, this article will only reflect on the normative perspectives on the issue of prayer. The epistemological point of departure is also the basis of what pastoral ministry entails. Louw (2010:73) formulates it as: 'The expression and representation of the sensitivity and compassion of the Scriptures' understanding and portrayal of God's encounter, intervention, interaction and involvement in our human being'. In providing normative perspectives on the issue of prayer, I will reflect on the interpretation of the Lord's Prayer and God's interaction and involvement in the life of the believer, to enable the counselee to create a life of justice and peace. Pastoral counselling is aimed at influencing, changing, renewing and healing for the counselee. These four theological issues concern the Holy Spirit as the immanent presence of God in the heart of the believer and communication with God through prayer as the point of intimacy between God and the believer (Louw 2000:429).

The research question that will be investigated is, can the Lord's Prayer during the process of pastoral guidance be a paradigm for restorative justice in a broken community? Questions resulting from this include among others: would the individual healing and transformation be limited to the person's own life, or in which ways can the collective realisation flow from it? In an attempt to answer these questions, a comparative literature study on the Lord's Prayer is carried out from a Reformed perspective. The scope of this article is focused on the role of the Lord's Prayer in the pastoral counselling process.

Following the suggested method, the article will unfold as follows:

- Description on the importance and unique place of prayer within pastoral care.

- The Lord's Prayer in the pastoral counselling process towards healing of brokenness.

- The Lord's Prayer as a paradigm for restorative justice in brokenness.

- Implications for the pastoral counselling process.

- Description on the importance and unique place of prayer within pastoral care.

In providing a framework to depart from, it is necessary to describe the importance and unique place of prayer within pastoral care. The dialogue about the place and use of prayer in pastoral guidance has been polarised as a conservative versus liberal issue (Jordan 1991:129). On the one end of the continuum, there is a tendency to minimise the use of the behavioural sciences and to maximise the use of prayer and scripture in pastoral counselling. The other end of the continuum is just the opposite, where the use of behavioural sciences is maximised and prayer and scripture minimised. Saying this, is to acknowledge that I am aware of the discourse, but it lays outside the boundaries of this particular article where the point of departure is that of a Reformed theology, where scripture and prayer are primary in pastoral guidance, and although aspects of behavioural sciences are taken into account, it is consider as secondary to scripture and prayer. It is, furthermore, important for the counsellor to be aware of the religious beliefs of counselees, because it is unethical for counsellors to push their faith onto counselees (Towns 2011:144). Implementing verbal prayers in the counselling guidance process must be performed with the consent of the counselee. On the other hand, covert prayers, where praying for counselees outside the counselling session or silently during the session, is always appropriate.

Effective use of prayer in pastoral guidance begins with understanding the nature and function of prayer. Prayer is an intimate act of communion with God. To pray, is to pour your heart and inner being out in the midst of God. Prayer is an expression of worship and dependency on God, and it unleashes the power of the Holy Spirit in the life of the believer (Towns 2011:142). Therefore, it is important to understand the connection between the living presence of God (inhabitation) and forthright communication with God (communio) in order to appreciate the uniqueness of prayer in pastoral care (Louw 2000:429). To understand the role of prayer in pastoral guidance it is also important to acknowledge that prayer is more than mere communication with God; it is rather a faith reaction towards God which presumes a relationship grounded in trust and salvation (Louw 2000:429). Prayer is part of every therapeutic encounter, whether the counsellor or the counselee is aware of it or not, because every human being is created to be in communication with God (Jordan 1991:134). Counselees overcome with guilt, are generally involved in silent prayers of the heart, filled with distortion, self-destruction and desperation. The incorporation of prayer in the process of ongoing pastoral care and guidance can be of particular help to counselees who struggle with painful memories from their past.

Prayer can have a threefold role in pastoral counselling: praying as the counsellor for the counselee, directing the counselee to pray for him- or herself, and praying for the actual healing process (Towns 2011:142). When directing a counselee to pray for him- or herself, it is important to determine what the counselee's image, perception or notion of God is, as this will determine his or her attitude towards God and the needs being prayed for. The content and focal point of prayer must not be God's provision as such, but God himself (Louw 2000:432). A vital question about prayer remains: is it about the believer's wishes addressed to God, or about God who hears and understands the need for spiritual and sometimes physical healing? Prayer will always have an influence on the counselee, because no one is left untouched whilst reflecting on God and remembering his salvation deeds of the past. Prayer, as remorse and confession of guilt, brings the therapeutic effect of relief, liberation and salvation to the counselee (Louw 2000:437). In prayer the counselee looks back at his or her own life, remembering 
God's interaction and intervention in difficult times; and the knowing and remembering bring inner peace, comfort and gratitude towards God, who is faithful and trustworthy.

Providing this short description of the importance and unique role of prayer in pastoral care and guidance, I now want to focus on the specific role of the Lord's Prayer in pastoral counselling.

\section{The Lord's Prayer in the pastoral counselling process towards healing of brokenness}

Brunsdon (2015:1) explains that the pastoral frame of reference used to focus on brokenness can be described as a disease model and argues that much pastoral energy is lost in determining the spiritual and social brokenness, which results in the counsellor neglecting to confirm certain positive or edifying paradigms as preventative to brokenness. The use of the Lord's Prayer during the pastoral guidance process is an example of a constructive paradigm to focus pastoral work. In times of intense inner turmoil people can sometimes not formulate their own words into a prayer other than the plea of, 'Lord, please help me'. In this regard Jesus himself provides comfort in that believers need not use a torrent of words to be heard, but should rather become still in the presence of the Lord (Coram Deo). Breed (2005) describes it as follows:

Coram Deo goes hand in hand with sursum corda, which means to lift your heart up to God and to come consciously into his presence in your thoughts. Living in the presence of God (Coram $D e o$ ) therefore requires that the human being would continuously lift his heart up to God (sursum corda). Continuously and sincere sursum corda leads to, and is, a definite prerequisite for Coram Deo. (p. 3)

Although God also hears and answers the intense plea of, 'Lord, please help me', the Lord's Prayer offers a structure that can help order the turmoil of emotions that are experienced by the counselee, but can sometimes not be expressed verbally. It is, furthermore, dangerous to view prayer as a technique which can be taught in pastoral care (Louw 2000:432). Prayer truly is a gift of God's grace and does not depend on the dignity of human beings. The personal impact of prayer on the individual is unpredictable; at best it requires a position of humility, dependence and surrender to God. To pray is to acknowledge human need, lack and weakness; yet prayer springs from a foundation of trust grounded in God's goodness (Dugdale 2012:31).

With this in mind we now move to a discussion of the Lord's Prayer in some detail. Most researchers agree on dividing the Lord's Prayer into two main parts. The author relates to the explanation that Felde (2015:65-72) provides of the Lord's Prayer and therefore provides an own schematic explanation (see Box 1).

When this structure is further analysed, it becomes evident that the first grand petition is divided into three single
BOX 1: Lord's Prayer.

\begin{tabular}{|c|c|}
\hline First grand petition: 'Be God to us' & Our Father which art in heaven \\
\hline Be God to us in our words & Hallowed be thy name \\
\hline Be God to us in our thoughts & Thy kingdom come \\
\hline Be God to us in our deeds & $\begin{array}{l}\text { Thy will be done in earth, as it is in } \\
\text { heaven }\end{array}$ \\
\hline \multicolumn{2}{|l|}{ Second grand petition: 'Be good to us' } \\
\hline Be good to us in our present needs & Give us this day our daily bread \\
\hline $\begin{array}{l}\text { Be good to us in things of the past that } \\
\text { still hurt us through guilt or blame }\end{array}$ & $\begin{array}{l}\text { And forgive us our debts, as we forgive } \\
\text { our debtors }\end{array}$ \\
\hline $\begin{array}{l}\text { Be good to us in things in the future that } \\
\text { already hurt, by making us afraid }\end{array}$ & $\begin{array}{l}\text { And lead us not into temptation, but } \\
\text { deliver us from evil }\end{array}$ \\
\hline $\begin{array}{l}\text { Basis for the grand petitions - the power } \\
\text { belongs to God, not to us or to the } \\
\text { prayer }\end{array}$ & $\begin{array}{l}\text { For thine is the kingdom, and the power, } \\
\text { and the glory, for ever }\end{array}$ \\
\hline
\end{tabular}

thoughts which together express the fullness of a relationship with God (Felde 2015:67). In pastoral counselling one of the aims is to lead a counselee to a personal relationship with God where the counselee serves God with his thoughts, words and deeds. The second grand petition asks God systematically and comprehensively for relief from all possible woes that could disturb God's children (Felde 2015:68). This is another aim of the pastoral counselling process. The grand petitions link up with what Louw (2010:73) described as a 'portrayal of God's encounter, intervention, interaction and involvement in our human being' in our present, past and future needs. Prayer is a relationship with God, so counselees' prayers connect them with God's love, forgiveness and an insight in their purpose in life (Towns 2011:143). The counselee experiences hope, peace, renewed joy and a stronger self-identity and selfdetermination. Therefore, the Lord's Prayer has an individual and a collective sense. Individually each petition of the Lord's Prayer with its specific focus, leads the believer eventually to inner healing, transformation, faith and redemption, which then can result in a collective sense of merciful, sacrificing and restorative justice as the counselee takes action to help fellow human beings.

\section{The Lord's Prayer as a paradigm for restorative justice in brokenness}

The biblical call to justice is based foremost in the context of love. Straub (2011:157) stated that true soul care is about understanding the power of love and living it in an effort to help fellow human beings. True love that comes from Christ compels us to take action to help those who are hurting. The Bible clearly defines an inherent correlation between beliefs and actions; from material possessions to emotional and spiritual care for others. Justice is about stepping into the counselee's stories of brokenness, but the responsibility of justice is truly about God's glory alone and bringing about his redemption in the world (Straub 2011:158).

As mentioned earlier, Felde (2015:66) divided the Lord's Prayer into two main themes, but he continues to show the correlation of the themes with the summary of the Ten Commandments. In Matthew 22:37-39, Jesus summarises the entire law in two commandments of love to God and 
love to the neighbour and the self. The first commandment focuses on the relationship between God and humans, and the second on the interpersonal relationship between people. The Lord's Prayer also ripples outwards from the supplicant's own needs to the fulfilment of the love commandment towards God and other people. Ultimately there is a progression from an individual sense to a collective sense when the counselee starts to outwardly express a newly-found wholeness in Jesus. The counselee's focus shifts from the focus on satisfying their own needs that come from inner brokenness, to a lifestyle of justice, peace and joy. A healthy society consists of healthy individuals. According to Van der Walt (1999:83), a believer's relationship with God is actualised in their relationship with his or her fellow human beings. He bases this statement on the central, fundamental and all-encompassing love commandment and comes to the conclusion that love of the self, of fellow humans and of God is inextricably linked. Van der Walt (1999) emphasised it as follows: 'In my love for my fellow human beings - and not in addition to it -I love God!'.

Van der Walt (1999:84) called this the three-dimensional perspective of the Bible on human responsibilities and rights, namely, the individual's responsibility towards his or her fellow human beings, the fellow humans' responsibility towards the individual, and both are based on the common responsibility towards God. Opposed to this, Van der Walt (1999:84) replaced responsibility with right or claim. In other words, the love commandment is not only the responsibility of believers, but also the mutual right or claim based on God's all-encompassing right or claim on man. This perspective emphasises the responsibilities, rights and claims of the broken. If they are not reached out to or cared for, a life of restorative justice cannot realise. The same thought process can be applied to the Lord's Prayer. As the believer found restorative justice in Jesus, he or she has the responsibility to show justice towards their fellow human beings. The personal needs that we pray for in the Lord's Prayer ripple outwards when we pray for society and with the prayer (ora), come the actions (labora). According to Felde (2015:72), the petitions in the Lord's Prayer are formulated in such a way as to remind the supplicant that the ora is not far removed from the labora. In this way the praxis of the pastoral guidance process is not limited to the consultation room, but it ripples out to the pastoral ministry to all people. Ultimately this is one meaning of our in the Lord's Prayer. As a religious being the individual also lives directly before the face of God, who calls everyone to his service. This service is fundamentally aimed at the responsibility of expressing the love commandment. The Lord's Prayer forms a paradigm that reflects the love commandment because it addresses every human need of the past, present and future.

The author agrees with Van der Walt's (1999:120) suggestion of a society developed according to biblical values, but adds the insights of the role of the Lord's Prayer as a paradigm for restorative justice in brokenness. For the sake of logical order, it is presented in columns (see Table 1).

An essential distinction has to be made regarding the work of the Holy Spirit. According to Koopman (2007:4), believers participate in the work of the Holy Spirit to fully actualise the kingdom life, which is a reality in Christ, for everyone and for all of creation. Torrey (1996) explained:

Love is the sum of holiness, 'the fulfilment of the law' (Rom. 13:10). Love is what we all most need in our relations to God, to Jesus Christ, and to one another, and it is the work of the Holy Spirit to root and ground our lives in love. (p. 135, [author's own emphasis])

TABLE 1: Lord's Prayer as a paradigm for restorative justice in brokenness.

\begin{tabular}{ll}
\hline $\begin{array}{l}\text { Developing society according to biblical values } \\
\text { (Van der Walt 1999:120) }\end{array}$ & $\begin{array}{l}\text { The Lord's Prayer: A paradigm for restorative justice in brokenness } \\
\text { (Expansion by author) }\end{array}$ \\
\hline
\end{tabular}
(Expansion by author)

Fundamental driving force

Obedience to God's will: Love for Himself and neighbours

Believers approach God in prayer as dependents. This implies that believers realise their own (Mt 22:37-40)

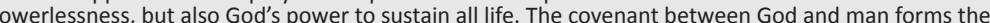
basis for prayer. The Lord's Prayer is given as a command by Jesus in the sermon on the mount.

\section{Personal values}

A responsible answer to God's central love commandment in different ways: service, charitableness, care, enrichment of the relationship with fellow human beings and the environment, etc.

A closer look at the Lord's Prayer shows two comprehensive petitions and relates it to the expression of the love commandment. The supplicant finds inner healing and restored justice, firstly in the restoration of his or her relationship with God, and secondly through addressing his or her needs in the present, pain of the past or expectancy of the future. The believer can express their creational calling responsibly in society based on the inner redemptive healing work of God.

\section{Social values}

An abundance of social values like loyalty (marriage), care (family), stewardship (business), justice (state), etc.

Social values based on a Christian worldview are sustained by a realisation and expression of our concept in the Lord's Prayer. The supplicant has a social responsibility, but also the right and claim to his or her fellow human beings, and vice versa. It is based on their mutual responsibility to God.

\section{Social structure}

Structural variety of marriage, family, school, university, church, state, business, sport organisations etc. Freedom and opportunities to fulfil the human calling in these structures in a balanced, unforced manner.

\section{Needs}

Just enough to sustain a diverse human existence, to enjoy freedom and to bear fruit.

Social structures are developed according to Biblical principles as reflected in the Lord's Prayer. The prophetic input of the church is important in the guidance and formation of social structures.

The Lord's Prayer has the potential to guide the supplicant to a restored relationship with God, himself and others. The human being can therefore now live from their creational purpose, to populate the earth

\section{Result (true development)}

Complete human welfare (not only prosperity) and peace (shalom)

Complete human welfare (not only prosperity) and peace (shalom). Said differently: a lifestyle of justice, peace and joy that is effected by the Holy Spirit. There is a paradigm shift from an individual sense to a collective sense. The foundation for this lies in the declaration that the kingdom, the power and the glory belongs to God.

Source: Van der Walt, B.J., 1999, Godsdiens en samelewing. Christelike betrokkenheid op die markplein, Wetenskaplike bydraes van die PU vir CHO, Potchefstroom 
Denton (2014:6) also mentioned the crucial work of the Holy Spirit in believers as supported by scripture (Jn 14:16-17; 16: 8, 13; Ac 9:31; Rm 8:26-27) that describes the Holy Spirit as the counsellor, comforter, helper and advocate. In the relationship between God and humans, God provides and cares for humans through the pneumatological dynamics of the Holy Spirit. Therefore, the essential basis for healing of brokenness which will lead to restorative justice is the work of the Holy Spirit. The Holy Spirit does not only heal the believers, he also guides them in prayer. Pastoral counselling is unique because it depends not only on willpower to be responsible, but also on God's enabling, indwelling power of the Holy Spirit. This is not to say that the counselee has no responsibility. Counselees' willingness and attempts to be healed must be joined with God's encounter through his Holy Spirit (Minirth 2003:2).

The Lord's Prayer is furthermore not limited to either a personal or communal context; it serves as a guide for prayer in all circumstances (Dugdale 2012:32). Those who pray this prayer pray as part of and on behalf of the whole community of those dependent on God. The Lord's Prayer is uncompromising in presenting to us a vision of the way things should be, rather than the way they are. As we pray the Lord's Prayer, even if circumstances do not change immediately, we are reminded to direct our lives so that we live in a way that seeks to fulfil the commandment of love. Taking all the above in consideration, the focus shifts now to the implications for the pastoral counselling process.

\section{Implications for the pastoral counselling process}

Making use of the Lord's Prayer in the pastoral counselling process does not mean that it must form a methodological guide for the way to approach prayer, but rather that a more in-depth consideration of what it actually means will deepen the prayer journey (Dugdale 2012:37). Prayer becomes supernatural when it becomes a habit, a mere reciting of words, in which the believer does not truly worship God. McNair (2005) did a study on Luther's writings on the Lord's Prayer and concludes:

Luther's approach to the Prayer differs from that of the medieval prayer books in that his goal is to teach the laity to use the structure and petitions of the Prayer as a basis for developing their own prayers, rather than simply repeating the Prayer a prescribed number of times a day using repetitive methods to such as the rosary. (p. 42)

In the counselling room the comprehensive meaning of each petition is more important than merely reciting the prayer. Luther referred to the mere recitation of the prayer as the abuse of prayer and if this is the case, prayer becomes a way to manipulate God. McNair (2005:42) links the recitation of prayer with the use of God's name in vain. Religion without true communion with God, allows prayer to be degenerated into a meaningless ritual (Louw 2000:433). Appealing to God in prayer implies that the believer has a relationship with God. The first implication for the counselling process is therefore that the counselee should be carefully guided to insight into the state of his or her relationship with God. In this regard Van Rensburg (1996:153) has already pleaded for the covenant as proprium for the pastorate with the argument that the covenant and the doctrine of selection are two of the most important foundational structures of the Bible and together form the reformed doctrine. According to Becker (as quoted by Van Rensburg \& Hoffman 2003:250), pastoral care will be more successful the closer the pastoral guidance process is to the covenant relationship. The introductory words of the prayer are significant. Of all the names of God, Father shows the more personal relationship between God and the believer, and according to Luther (McNair 2005:42), it is the name that pleases God most. We indicates the plural, so prayer is not just for the individual, but also for the collective. The use of Father also reminds of the prophet Isaiah and comforts the counselee with the knowledge that his or her heavenly Father is different from an earthly Father (cf. Is 43:27). Within a Father-child relationship, prayer reflects the quality of the communion and the intimate communion is eventually more valuable that the component of asking (Louw 2000:431).

In spite of the comfort, there is also a clear distinction between God and the supplicant with the words that is in heaven. On the one hand there is an indication of a close relationship, followed by the paradox of distance on the other hand. God is a human being's Father, but he is in heaven and humans are on earth. Near, but far. According to Luther (McNair 2005), the supplicant then acknowledges:

\begin{abstract}
... That he or she is wretched and all alone on earth ... far from his or her father's country among strangers, desolate and miserable. These seven petitions are seven reminders of our wretchedness and poverty by means of which man, led to knowledge of self, can see what a miserable and perilous life he or she leads here on earth. (p. 42)
\end{abstract}

This paradox is the second implication for the counselling process. The counselee should be guided to insight in the eschatological tension of already, but not yet completely. The believers find their hope in Jesus Christ through the kingdom of God, which is already present in the current circumstances of the world, although not fully (Moltmann 1967:16). For this reason no illusion should be created with the counselee of 'heaven on earth' like some prosperity theologians proclaim. When one prays for the coming of God's kingdom, it is for the ability through the working of the Holy Spirit to express Jesus' teachings as presented in the sermon on the mount (Hinkle 2002:13). In the New Testament, Paul attempts to change believers' perspective by encouraging them to focus more on the eschatological dimension of prayer, rather on the detail of their problems and needs (Louw 2000:435). Prayer thus flows from the presupposition of God's faithfulness, where the victorious dimension of salvation and healing becomes the point of departure for the counselee.

The third implication for the pastoral guidance process is a natural result of the correct handling of the previous implication, namely that the guidance does not end in the consultation room. Over the course of the pastoral guidance 
process the counselee is, in the first instance, guided to an understanding of the covenant relationship with God, and in the second place to an understanding of the eschatological tension in the covenant relationship that results in insight into the needs of the present, the healing of the wounds of the past and to peace about the expectations of the future. The counselee can consequently express his or her creational purpose to serve society with his or her gifts based on their personal healing. Seamands (2003:171) referred to this as recycling grace. In light of this, forgiveness forms an important element of the pastoral guidance process. So much so that the deduction can be made that inner healing is not possible without forgiveness being given or taken as part of the Christian guidance process. Literature often refers to the petition that deals with forgiveness as the heart of the Lord's Prayer. Kendall (2010:125) emphasised the importance of this with his remark that it seems as if Jesus added a postscript to the prayer with an additional reference to forgiveness (Mt 6:14). With the restoration of inner order, there will be a spontaneous flow of love to fellow human beings. Felde (2015) made the following remark in this regard:

The requests in this prayer, even as they are directed at God, are also reflected back upon us who pray, so that as God moulds our intentions into faith and love, we become the means by which God restores peace and hope to the world. (p. 71)

French (2002:26) quoted Barth's commentary on prayer when he said that to fold one's hands in prayer is the beginning of an uprising against the disorder of the world. The use of the Lord's Prayer in the pastoral guidance process is the beginning of a process to (re)create inner order, which has the potential to flow outward to the (re)creation of order in a broken society. In this process the Lord's Prayer is not merely a rhyme that is recited, but guidance for the counselee to turn his or her heart to God so that their prayer may be heard by God.

\section{Conclusion}

The Lord's Prayer truly reflects God's heart for his people, because all human needs are covered in this relatively short prayer. This article focussed on the use of the Lord's Prayer as part of the pastoral guidance process, which creates a paradigm for restored justice in society. Prayer is on the one hand presented as a positive and edifying paradigm that prevents further brokenness, and on the other hand as a prayer that can provide structure to the turmoil of inner emotions with the aim of working through and dealing with painful emotions. The counselee is guided to focus on God's perfect character and in so doing shifts his or her focus from a problem-centred life to a life of surrender to God. Two main themes of the Lord's Prayer were discussed, namely, humans relationship with God, and human's dependence on God for life. The main themes were related to the love commandment, which in itself aims to guide the believer to the realisation of a wider responsibility towards society in respect of merciful, sacrificing, restored justice that heals brokenness. As such the love commandment becomes central, fundamental and comprehensive in the expression of the counselee's creational purpose as part of their striving for full human welfare and peace through a life of justice, peace and joy through the Holy Spirit. In the process there is a paradigm shift from an individual sense to a collective sense. The eschatological tension found in the Lord's Prayer guides the counselee to insight in the three-dimensional perspective on the Bible and on human responsibilities and rights.

\section{Acknowledgements Competing interests}

The author declares that she has no financial or personal relationships which may have inappropriately influenced her in writing this article.

\section{References}

Breed, G., 2015, 'Ministry in the presence of God (Coram Deo) according to Exodus', In die Skriflig 49(3), 1-9. http://dx.doi.org/10.4102/ids.v49i3.1842

Brunsdon, A.R., 2015, 'Wisdom as outcome of the pastoral process: Reflections on a positive pastoral narrative approach', In die Skriflig 49(3), 1-8. http://dx.doi. org/10.4102/ids.v49i3.1873

Denton, R.A., 2014, 'Exploring Biblical reformational theology as a normative perspective for Christian psychology', In die Skriflig 48(1), 1-11. http://dx.doi. org/10.4102/ids.v48i1.1791

Dugdale, K., 2012, 'Understanding the Lord's Prayer as a paradigm for prayer', The New Zealand Journal for Christian Thought and Practice 19(3), 30-37.

Felde, M., 2015, 'The Lord's Prayer: Who could ask for anything more?', Word \& World 35(1), 65-72.

French, H., 2002, 'The Lord's Prayer: A primer on mission in the way of Jesus', Word \& World 22(1), 18-26.

Hinkle, M.E., 2002, 'The Lord's Prayer: Empowerment for living the sermon on the mount', Word \& World 22(1), 9-17.

Jordan, M., 1991, 'Prayer and meditation in pastoral care and counselling', in H.W. Stone \& W.M. Clements (eds.), Handbook for basic types of pastoral care and counselling, pp. 129-147, Abingdon Press, Nashville, TN.

Kendall, R.T., 2010, The Lord's Prayer. Insight and inspiration to draw close to him, Chosen Books, Grand Rapids, MI.

Koopman, N., 2007, 'The Lord's Prayer - An agenda for Christian living', Journal of Reformend Theology 1(2007), 4-5. http://dx.doi.org/10.1163/156973107X182604

Louw, D.J., 2000, A pastoral hermeneutics of care and encounter, Lux Verbi BM, Cape Town.

Louw, D.J., 2010, "Care of the human "soul" in contemporary theological formation: From "kerygmatics" to "fortigenetics" in pastoral anthropology', NGTT 51(3\&4), 70-81.

McNair, B.G., 2005, 'Luther and the pastoral theology of the Lord's Prayer', Logia 14(4), 41-46.

McNicol, A.J., 2004, 'The Lord's Prayer: The touchstone of Christian spirituality', Christian Studies 20(1), 5-21.

Minirth, F., 2003, The Minirth guide for Christian counsellors, Boardman \& Holman Publishers, Nashville, TN.

Moltmann, J., 1967, Theology of hope, SCM Press, London.

Müller, J., 2005, 'A postfoundationalist, HIV-positive practical theology', Praktiese Teologie in Suid-Afrika 20(2), 72-88.

Osmer, R.A., 2008, Practical theology: An introduction, Eerdmans, Grand Rapids, MI.

Seamands, S., 2003, Wounds that heal, IVP Books, IL.

Straub, J., 2011, 'Social justice', in T. Clinton \& R. Hawkins (eds.), The popular encyclopaedia of Christian counselling: An indispensable tool for healing people with their problems, pp. 142-144, Harvest House Publishing, Eugene, OR.

Torrey, R.A., 1996, The person and work of the Holy Spirit, Whitaker House, New Kensington, $\mathrm{PA}$

Towns, E., 2011, 'Prayer in counselling', in T. Clinton \& R. Hawkins (eds.), The popular encyclopaedia of Christian counselling: An indispensable tool for healing people with their problems, pp. 142-144, Harvest House Publishing, Eugene, OR.

Van der Walt, B.J., 1999, Godsdiens en samelewing. Christelike betrokkenheid op die markplein, Wetenskaplike bydraes van die PU vir CHO, Potchefstroom.

Van Rensburg, J., 1996, 'Verbond en pastoraat. Perspektiewe vir die ontwerp van 'n paradigma', Nederduits Gereformeerde Teologiese Tydskrif 1(1), 152-165.

Van Rensburg, J. \& Hoffman, L., 2003, 'Die impak van die verbond op 'n paradigma vir pastoraat', Acta Theologica 2(1), 239-253. 